\title{
Psychoanalytic Representation of Poverty, Corruption and the Nigerian Church in Chukwuma Ibezute's Stain on a White Robe
}

\author{
Solomon Awuzie \\ http://dx.doi./org/10.4314/ujah.v20i1.3
}

\section{Abstract}

This article contends that despite the fact that Nigeria is still referred to as a country that is blessed with enormous natural resources, writers and scholars have referred to it as a country that harbours some of the poorest people in the world. As a result, the act of swindling popularly known as "419" has taken the centre stage. Some of the fraud stars now feign to be pastors and prophets and own churches where they extort money and other valuables from their victims. This antisocial behaviour is noted in Chukwuma Ibezute's White Robe. The novel depicts how poverty and corruption have crippled the present day Nigerian churches and got them almost all ruined.

Keywords: Poverty, Corruption, Christians, Church(es), Chukwuma Ibezute, Nigeria(ns)

\section{Introduction}

Nigeria, even though referred to as a country that is blessed with enormous natural resources, in recent times many literary critics and scholars have referred to it as a country that harbours some of the poorest people in the world with as many as 69 percent of the population, which is about 112.47 million Nigerians living below the poverty line' (Hussaini AbduIt,6).In his book, Abdult posits that this case of poverty amidst plenty is as a result of corruption. 
This is because stealing of and misuse of the country's resources that would have been used to provide 'wealth-creating infrastructure' for its citizens (6). Oduwole Tajudeen and Fadeyi Adebayo described poverty in Nigeria as an economic situation where a household income is insufficient to meet the minimum nutritional need for growth and long-term survival and that it is a vicious circle of multiple adverse circumstances that limit the choices of the poor' (106). Omoniyi Victor Ajulor also notes that with the way Nigeria is moving, it is clear that the country is retrogressing 'to become one of the 25 poorest countries in the world' (237). With extreme poverty among the people, Charles Nnolim posits that, Nigerians now depict 'a people adrift, hedonistic [...]' (229) and the country now represent a 'society without direction, operating on the principle of catchment, geographical spread, federal character, disadvantaged state where the individual is irreligious, debauched and thinks with his crotch. Women took to whoring as business where they are either trafficked by a syndicate or quite often traffic themselves by migrating to the flesh pots of Europe' (158). Seeing the level of poverty in the country, Ben Okri lamented on the state of the country through one of his characters in The Landscape Within, thus: 'I think ours is another damned generation of loss.' (qtd in Nnolim, 326) Camillus Ukah, through one of his characters in When the Wind Blows, says: 'I weep for this generation. I weep for a generation hunted by its own machination and ensnared by its own trap' (166).

However, in other to survive this extreme situation of poverty, most Nigerians get involved in robbery and '419ing'. Since robbery involves a lot of risks, only a few people are into it. '419ing'has therefore taken the centre stage and has also taken a different form. Since, as Karl Max rightly observed, 'Religion is 
the opium of the masses' $419 \mathrm{ers}$ '2 now feign to be pastors and prophets and own churches where they extort money from the people. One of the reasons they seem to be succeeding is because Nigerians hardly doubt pastors or prophets, especially when they claim they are sent by God. Another reason for this is the fact that one needs no capital to begin church in Nigeria. And this has led to the proliferation of churches in Nigeria to the extent that makeshift batchers are now built by the road-sides and shops are now rented for church purposes. It is therefore not surprising that most Nigerian writers are beginning to reflect this situation in their fictions. Among these Nigerian writers is Chukwuma Ibezute. Ibezute's fictional works reflect the day-to-day activities and problems associated with modern Nigerian society. His novel, Stain on a White Robe, for instance, is about 'the corrupt Nigerian religious (church) system' (see Awuzie), while his other novels are about other aspects of the Nigerian society. As Michel Zeraffa rightly observed, 'it is through its formal character and through the techniques used to create that formal character that a work of art exposes reality' (10),through the characters of the novel, Stain on a White Robe, how poverty and corruption crippled the modern Nigerian churches and got them all ruined is revealed.

\section{Poverty and Corruption in Ibezute's Stain on a White Robe}

Like many Nigerian fictions that reveal the extent of poverty in Nigeria, Stain on a White Robe exposes the level of poverty in the country and links it with the proliferation of churches in Nigeria. Of most importance in the novel is that it depicts that poverty and corruption have eaten deep into the churches and, like the country itself, the church is at its verge of collapse. The novel is set in the contemporary time when poverty and corruption are at crescendo at a time when one does anything to survive. The novel is 
dominated by Christian characters that are all out to deceive others in order to make money for themselves. This also accounts for all that happened at the end of the novel. This goes to say that any society where the majority of its populace is made up of those who earn their living through deceit is heading for doom. Among these corrupt characters are Reverend Pastor Martin Okeke, Archbishop Ronald Mezie, Sir Matthew Agu and Christie Okonga. The thing of worry in the novel is that apart from exhibiting their corrupt practices in their individual churches, they go extra miles to bend the rules governing the Nigerian Christian society to suit them. The novel further reveals that most of these corrupt reverend pastors are not genuine; they are like the '419ers', who become reverends, pastors or prophets in order to 'get away from restlessness and competitive challenges of the world and its attendant worries and heartbreaks' (30). The novel explains that:

Once they successfully passed through the rigours of studentship and got ordained, those who chose the vocation to run away from the hardship and difficulties of the world felt they had been authorized to lead a normal life like their contemporaries in the wider world. But in practice, they would maintain their ordination and vocation ceremoniously, without spiritual uplift and growth and would not care to live by their teachings. Yet, most often, these flesh and world clergymen grew envious of their colleagues who, due to their devotion to their vocation and spiritual commitment to their calling, were elevated by God to perform miracles and wonders [...] Some church ministers who, by their calling, preached the gospel and championed the cause of people loving one another, sometimes, out of envy and jealousy, witch-hunted their 
colleagues. A few of them sometimes carried out nefarious acts of poisoning and murder. (30)

Reverend Pastor Martins Okeke and Archbishop Ronald Mezie are used to represent this group of Christian leaders in Nigeria. While Archbishop Ronald Mezie represents leaders of the Pentecostal Churches, Reverend Pastor Martin Okeke represents Reverend Fathers of the Catholic Churches in Nigeria. The difference between the two Nigerian churches is seriously stressed in the novel. For instance, since corrupt Archbishop Ronald Mezie, of 'Reapers Christian Believers Fellowship' (RCBF) discovered that to attract more people to his church he needed to perform 'miracles', he travelled to India to acquire powers and visited Babalawos ${ }^{3}$ for evil powers. Reverend Pastor Martin Okeke, on the other hand, does not need such power because CdHGM does not attach so much importance to the issues of miracles. Reverend Pastor Martin Okeke's greatest challenge is the issue of women and the acquisition of wealth. Reverend Pastor Martin Okeke is an example of those corrupt reverend fathers in Nigeria who are chronic womanisers and who would go extra miles to defraud the church in order to impress a lady or woman they have their eyes on. During one of his conversations with Henry Onyema, Ronald Mezie spoke for such clergies. Onyema had asked: 'But you told us here that you love the life of clergymen?' and in reply Mezie said:

Yes, I said so. Try to get my point. I said instead of wobbling up and down in search of elusive success like in my own case, becoming a clergyman who automatically becomes king the moment he is ordained has to be considered the best option. But the hard nut to crack lies in this condition of chastity and celibacy for life. Even if a morally-conscious man ignores these beautiful daughters of 
Eve who are moving about in their captivating and majestic gait, he cannot promise not to have at all, any woman he could fall back to. Unless the man is not healthy. Or, if he is castrated. Let us be realistic [...] (42-43)

Reverend Pastor Martin Okeke and Archbishop Ronald Mezie are the proverbial 'roadside mechanic that would not allow one know the distinction between the sane and the insane.'

Of interest in the novel is also the character of Chief Sir Matthew Agu who believes that church is business. Chief Sir Matthew Agu is like most Nigerian Christians who help to build the church with the intention] of reaping their investments later. $\mathrm{He}$ contributed to the building of RCBF and expected that he got some share of the offerings and tithes. When Chief Matthew Agu saw that Archbishop Ronald Mezie was not ready to share the offerings and tithes, he requested for the 'Sir' title. Christie Okonga is like Chief Sir Matthew Agu. She is not a clergy but is one of those through which the entire system is corrupted. She is also a business lady. She comes to church just to meet men of different vocations and to see if she can seduce them in order to get some money out of them. In order to make some money for herself, she sold her naive friend Loretta Onwe out for sex to Martin Okeke when Martin Okeke was a young seminarian. Having almost had sex with all the women in his church and was still not satisfied, Reverend Pastor Martin Okeke decided to secretly marry Loretta Onwe. Henry Onyema, Loretta's ex-husband, soon discovered and planned to expose the corrupt practices of Reverend Pastor Martin Okeke and his kinds in a symposium he was to organise at the Republican Stadium, Lagos.

In the novel, there are still some good Christian characters. Among this group of characters are Berthrand Ekwunike, Henry Onyema and Reverend Pastor Obed Dauda. At different times in 
the novel, Berthrand Ekwunike is used by Archbishop Ronald Mezie and Chief Sir Matthew Agu to enrich themselves without him realising it. At RCBC, where he was the administrative officer of the church without pay, he did all the preaching and made all the members to bring offerings and tithes, while Chief Sir Matthew Agu and Archbishop Ronald Mezie siphoned all the funds. This reveals that Nigerians are like those they cheat. Berthrand Ekwunike was loved by Chief Sir Matthew Agu and Archbishop Ronald Mezie. It is also depicted in the novel that Nigerians like corrupt people and hate those who try to do the right thing or who want to force others to do the right thing. Henry Onyema was such character that was used to demonstrate this fact. When Comrade Henry Onyema spoke out on the corruption that was ravaging the Nigerian church and the entire Nigerian society, he was found dead the next day by the corner of the road. Though before his death the Christendom today magazine expressed a similar fear:

How safe is Henry Onyema in a polarized African state whose government cannot guarantee the safety of her citizens? He is brave and may be factual but what's his arrangement for his security in a country with an increasing rate of kidnapping, assassination and brazen murder? (189) However, Reverend Pastor Obed Dauda, in one of his sermons, explained Henry Onyema's fate in a country like Nigeria: 'while we are talking of change, reforms and boomerang, let us not lose sight that the arrow does not rebound only when one does wrong or is guilty. Sometimes, actions intended to be for one's good, or for the betterment of the people boomerang to unpleasant consequences against the initiator' (144). 


\section{Conclusion}

From the study, it is obvious that all hope is not lost and that something can still be done to salvage the collapsing Nigerian churches. To save the churches, Reverend Pastor Obed Dauda is of the view that we should stop complaining and tackle the Nigerian church problem. This is because 'there's a saying that whenever an old man in the midst of children mimics crying, he has indirectly told the children around him to cry themselves numb' (178). Every genuine Christian should do everything to solve the problem and purge the church of corruption and all corrupt practices. The first way of achieving this is by giving sincere sermons and enlightenment campaign. Since it is a nationwide problem, Reverend Pastor Obed Dauda is also of the view that without enlightenment campaign, it will be -

[...] difficult to achieve change and reforms. A situation where someone like you, a university graduate and former civil servant does not know some basic things you are supposed to know, leaves much to be desired. No meaningful change can take place in a situation where a greater percentage of the citizenry is ignorant of its rights as citizens, and is typically illiterate in the country's current affairs and basic citizenship education. (144)

If the sermon and campaign fail to work, Henry Onyema's observation that Nigerian Christians 'should not relent in challenging evil and the agents of backwardness which stand on our way to greatness' (162) should be put to use. In order to match action for action, Nigerian Christians should stop patronising corrupt and 'fake' pastors, prophets, reverend pastors and reverend fathers] and stop allowing reverend fathers like Reverend Pastor Martin Okeke and pastors like Archbishop Ronald Mezie to have their ways. Since 'it is only he who teaches a man with ear-ache 
that usually gets exhausted by repeating himself and shouting' (155) let us not involve the government because 'that is the very root of corruption' (Camillus Ukah,121) or 'our politicians' because they 'have no value for history and do not learn from the past' (155).

However, the novel reveals that poverty in Nigeria can only be addressed if Nigerians sincerely want the problem to be solved. Unfortunately, Nigerians seem to be more interested in acquiring wealth and engaging in sex related activities. They seem not to be interested in societal values. Everyone is so engrossed in how to survive and be respected without seeing problem in the situation. These are the reasons why it could be difficult for the situation to change.

\section{Notes}

(1) In Nigeria parlance '419ing' means to swindle people of their money.

(2) '419ers' are persons involved in the act of '419ing.'

(3) Babalawos are what the Yoruba call witch doctors in their native tongue.

Solomon Awuzie

Department of English

Edo University Iyamho

sonsawuzie@yahoo.com 


\section{Works Cited}

Abdu, Hussaini. 'Foreword' in Corruption and Poverty in Nigeria: A Report. Abuja: Action Aid Nigeria, 2015 (i-iii)

Ajulor, Omoniyi Victor. 'Policy Implementation and Rural Poverty Reduction in Nigeria (An Analysis of the National Poverty Eradication Programme (NAPEP) in Ado-Odo OtaLocal Government Area, Ogun State)'Ist Annual International Interdisciplinary Conference AIIC 2013, 24-26 April, Azores, Portugal.

Awuzie, Solomon. 'Contemplating the fate of a ruined generation: Camillus Ukah's When the Wind Blows and Chukwuma Ibezute's Stain on a White Robe' Kafla 11(2) 2016 (50- 65)

'Good Wives and Bad Wives: Chukwuma Ibezute's Victims of Betrayer and Dance of Horror' Imbizo 6(2)2016 (1-11)

Ibezute, Chukwuma. Stain on a White Robe. Owerri: Cel-Bez Publishing Co. Ltd., 2004 (Revised Edition 2012).

Nnolim, Charles. 'A New Writer in a New Context: Camillus Ukah's When the Wind Blows ANA REVIEW 1 (Oct.) 2012 (158-164)

........ Contemporary Nigerian Fiction' Issues in African Literature. Yenagoa: Treasure Resource Communications Ltd, 2009 (228-243)

Oduwole Tajudeen and Fadeyi Adebayo. 'Gender, Economic Activities and Poverty in Nigeria'Journal of Research in Peace, Gender and Development (JRPGD) (ISSN: 2315568x) Vol. 2(7). 106-125, September, 2013

Okri, Ben. The Landscape Within. Ibadan: Heinnemann, 1998.

Ukah, Camillus Chima. When the Wind Blows. Owerri: Liu House of Excellence Ventures, 2007

Zeraffa, Michel. Fictions: The Novel and Social Reality. England: Penguin Books Ltd, 1976 